\title{
Process optimization, physicochemical characterization and antioxidant potential of novel wine from an underutilized fruit Carissa spinarum L. (Apocynaceae)
}

\author{
Abhishek MUNDARAGI ${ }^{1}$, Devarajan THANGADURAI ${ }^{1 *}$
}

\begin{abstract}
Carissa spinarum L., is a tropical underutilized fruit abundantly available during summer season, which is delicious to taste with an astringency flavor and fruity aroma. Hence, the present investigation was aimed at optimizing fermentation conditions for the production of wine and to assess its physiochemical composition and antioxidant activity. Response surface methodology coupled with central composite design was employed for the optimization studies. It was determined that fermentation temperature of $25^{\circ} \mathrm{C}, \mathrm{pH}$ of 3.5 and inoculum size of $10 \%(\mathrm{v} / \mathrm{v})$ resulted in quality wine with $8.3 \%(\mathrm{v} / \mathrm{v})$ of ethanol content. Further, physicochemical composition and antioxidant activity of the optimized wine was found to be significantly higher or on par with other tropical fruit wines reported previously. Sensory analysis indicated that wine was good in terms of overall acceptability. Thus, availability of C. spinarum fruits during their glut season can be utilized for winemaking and could generate revenue among rural households further adding significant input to the economy of fruit wine market.
\end{abstract}

Keywords: Carissa spinarum; fermentation; wine; antioxidant; nutritional composition.

Practical Applications: The results of the present study, indicates that C. spinarum fruit could act as potential substrate for the production of good quality fruit wine, having good taste with therapeutic properties. This in turn could generate revenues and shall create avenues among the people of rural communities.

\section{Introduction}

Fermentation is a widely accepted technique for the development of new products relatively associated with the modification of physical, chemical and sensory qualities, especially flavor and nutritional components. Alcoholic fermentation is largely employed for the production of beverages in which ethanol is a major constituent and other minor secondary metabolites are also formed. Wine is considered to be one of the oldest alcohol beverages. It is therapeutic in nature and its regular consumption has shown multiple beneficial effects against several disorders including cardiovascular diseases (Stoclet et al., 2004). The key components of wine are polyphenols, alcohols and volatiles that are known to have a significant role in enhancing the therapeutic nature of wine (Styger et al., 2011; Mena et al., 2012). Yeast plays pivotal role in winemaking that constitutes several enzymes that have profound effect on the production of ethanol and other secondary metabolites. Saccharomyces cerevisiae is widely employed for winemaking and hence, it has been commonly referred as 'wine yeast'. Yeast activity is mainly influenced by factors such as temperature and $\mathrm{pH}$. Which play crucial role in controlling the growth and metabolism rate of yeast and in synthesizing or transforming bioactive compounds in wine (Arroyo-López et al., 2009).

Underutilized fruits are good source of vitamins, minerals and energy. However, these fruits have lesser shelf life in comparable to that of other fruits unless they are properly preserved.
Carissa spinarum L., commonly called as 'wild karanda', is an underutilized wild fruit closely related to Carissa carandas L., belongs to family Apocynaceae. Ethnobotanically, the plant is used as medicine against several diseases and fruits are considered to be rich source of vitamin $\mathrm{C}$ and iron. Ripe fruits are used in making jam, jellies and pickles (Fatima et al., 2013). C. spinarum fruits contain following nutritional composition: moisture $81.05 \pm 1.97 \%$, proteins $2.07 \pm 2.04 \%$, fat $1.30 \pm 0.01 \%$, carbohydrates $18.66 \pm 0.25 \%$, calcium $29 \pm 0.57 \mathrm{mg} / 100 \mathrm{~g}$, phosphorus $32.1 \pm 0.05 \mathrm{mg} / 100 \mathrm{~g}$, iron $3.45 \pm 0.00 \mathrm{mg} / 100 \mathrm{~g}$, total phenolics $5.31 \pm 0.21 \mathrm{mg} \mathrm{TAE} / \mathrm{g}$ and total flavonoids $0.44 \pm 0.00 \mathrm{mg} \mathrm{QE} / 100 \mathrm{~g}$ (Chauhan et al., 2015).

Several statistical approaches have been under use to optimize the process factors for maximizing yield of the product. Response Surface Methodology (RSM) is one such approach that has been extensively studied and applied in bioprocess technology. It minimizes the number of observations and thus provides more precise and accurate results. Although production of wine from C. spinarum fruit is done locally, to our knowledge, availability of scientific reports are scarce. Thus, the main aim of the present study was to optimize the fermentation process conditions to achieve good quality wine with respect to high ethanol content by employing RSM statistical approach and to evaluate the aggregated effect of independent variables, viz. temperature, $\mathrm{pH}$ and inoculum size on ethanol content. 


\section{Materials and methods}

\subsection{Yeast inoculum preparation}

Yeast strain Saccharomyces cerevisiae (NCIM 3215) was procured from National Collection for Industrial Microorganisms, National Chemical Laboratory, Pune, India. The stock was cultured and maintained in the MGYP media with the following composition: $1.0 \mathrm{~g}$ glucose, $0.3 \mathrm{~g}$ malt extract, $0.3 \mathrm{~g}$ yeast extract and $0.5 \mathrm{~g}$ peptone, all in $100 \mathrm{~mL}$. For the yeast to grow, the temperature was kept at $25^{\circ} \mathrm{C}, \mathrm{pH} 6.5$ with an incubation period of 24-48 h in rotary shaker. This suspension comprised $3 \times 10^{6}$ yeast cells per mL. Further it was transferred on to a $2 \mathrm{~L}$ Erlenmeyer flask containing $500 \mathrm{~mL}$ of pre-sterilized C. spinarum fruit juice and incubated at $25 \pm 2{ }^{\circ} \mathrm{C}$ in a rotary shaker for a period of 12-24 h that was considered as inoculum for further optimization experiments.

\subsection{Fermentation of C. spinarum fruits}

Mature and healthy C. spinarum fruits were procured from rural areas of Uttara Kannada District in Karnataka, India. Fruits were cleaned, deseeded manually and the juice was extracted. $100 \mathrm{ppm}$ of $\mathrm{SO}_{2}$ was added in the form of potassium metabisulphite to inhibit the growth of unfavorable microorganisms. Sugar level in juice was adjusted to $22^{\circ}$ Brix using sucrose, $300 \mathrm{~mL}$ of which was taken in each $500 \mathrm{~mL}$ Erlenmeyer flasks, $\mathrm{pH}$ was set using $\mathrm{KOH}$ and citric acid and this ameliorated juice was further inoculated with wine yeast according to the respective runs as suggested in a Central Composite Design (CCD) matrix (Table 1). Finally, these flasks were subjected to fermentation for 21 days with varying incubation temperature according to the experimental design. After completion of fermentation process, produced wine was collected, centrifuged, clarified and then transferred in to sterile glass bottles for further analysis.

\subsection{Experimental design and optimization}

The experimental design and statistical analysis were performed according to the response surface methodology using Design Expert 7.1.6 (Stat-Ease Inc., USA) software. CCD was used in the optimization of ethanol production. Three independent variables, viz. temperature $\left(\mathrm{X} 1,{ }^{\circ} \mathrm{C}\right), \mathrm{pH}(\mathrm{X} 2)$ and inoculum size $(\mathrm{X} 3, \%)$ were considered for the experiment (Table 2). A $2^{3}$-factorial CCD matrix with six axial points $(a=\sqrt{3})$ and replications at the center points $\left(n^{\circ}=6\right)$ were chosen. A total of 20 runs were employed and all assays were done in duplicate.

\subsection{Physicochemical properties of fruit juice and optimized wine}

Total soluble solids (TSS) content of the C. spinarum juice and wine was determined in terms of ${ }^{\circ}$ Brix using a hand refractometer (0-32, Erma, Japan). The $\mathrm{pH}$ of the wine was determined using a digital $\mathrm{pH}$ meter (LI-120, Elico, India). Titrable acidity was determined by titration with $0.1 \mathrm{~N} \mathrm{NaOH}$ and expressed as percentage citric acid equivalents (\% CAE). Ascorbic acid was determined following the protocol described by Thimmaiah (1999). Association of Official Analytical Chemists (2005) methods were followed for determination of protein and other minerals
Table 1. Experimental design (CCD matrix) in terms of actual values.

\begin{tabular}{cccccc}
\hline \multirow{2}{*}{$\begin{array}{c}\text { Run } \\
\text { order }\end{array}$} & $\begin{array}{c}\text { Temperature } \\
\left({ }^{\circ} \mathrm{C}\right)\end{array}$ & $\mathrm{pH}$ & $\begin{array}{c}\text { Inoculum } \\
\text { size }(\% \mathrm{v} / \mathrm{v})\end{array}$ & Actual value & $\begin{array}{c}\text { Predicted } \\
\text { value }\end{array}$ \\
\hline 1 & 25 & 3.5 & 10 & 8.3 & 8.3 \\
2 & 25 & 3.5 & 10 & 8.3 & 8.3 \\
3 & 20 & 3 & 15 & 8.1 & 8.4 \\
4 & 16.6 & 3.5 & 10 & 5.8 & 6.0 \\
5 & 25 & 2.6 & 10 & 6.2 & 6.0 \\
6 & 25 & 3.5 & 1.6 & 4.8 & 4.8 \\
7 & 30 & 4 & 15 & 7.8 & 8.3 \\
8 & 20 & 4 & 15 & 7.3 & 7.0 \\
9 & 25 & 4.3 & 10 & 7.2 & 7.1 \\
10 & 20 & 3 & 5 & 4.6 & 4.2 \\
11 & 25 & 3.5 & 10 & 8.3 & 8.3 \\
12 & 25 & 3.5 & 10 & 8.3 & 8.3 \\
13 & 30 & 4 & 5 & 7.7 & 7.6 \\
14 & 30 & 3 & 15 & 7.8 & 7.8 \\
15 & 33.4 & 3.5 & 10 & 8.2 & 7.7 \\
16 & 20 & 4 & 5 & 4.8 & 5.0 \\
17 & 30 & 3 & 5 & 4.5 & 5.0 \\
18 & 25 & 3.5 & 18.4 & 9.1 & 8.9 \\
19 & 25 & 3.5 & 10 & 8.3 & 8.3 \\
20 & 25 & 3.5 & 10 & 8.3 & 8.3 \\
\hline & & & & & \\
\hline
\end{tabular}

Table 2. Factors involved in central composite design in terms of actual values.

\begin{tabular}{cccc}
\hline Factor & Name & Low value & High value \\
\hline $\mathrm{X}_{1}$ & Temperature & 15 & 30 \\
$\mathrm{X}_{2}$ & $\mathrm{pH}$ & 3 & 4 \\
$\mathrm{X}_{3}$ & Inoculum size & 5 & 15 \\
\hline
\end{tabular}

using Atomic absorption spectrophotometer (SL-168, Elico, India). Ethanol content was determined by spectrophotometer (Caputi et al., 1968).

\subsection{Qualitative analysis of alcohols}

Qualitative analysis of the alcohols was carried out using Gas Chromatography equipped with Flame Ionization detector (GC-FID) (GC-2010, Shimadzu, Japan). Zebron Wax plus capillary column containing polyethylene glycol was used. The temperature program followed was: $40^{\circ} \mathrm{C}$ ( 1 minute hold) to $70^{\circ} \mathrm{C}$ at a rate of $5^{\circ} \mathrm{C}$ per min and to $220^{\circ} \mathrm{C}$ at a rate of $25^{\circ} \mathrm{C}$ per min for $3 \mathrm{~min}$. The carrier gas used was nitrogen and flow rate was maintained at $1 \mathrm{~mL}$ per min with an injection volume of $0.5 \mu \mathrm{L}$ (Archana et al., 2015).

\subsection{Determination of total phenolic and flavonoid content}

Total phenolic content (TPC) was determined according to the protocol of Singleton et al. (1974) with slight modification. Folin-Ciocalteu reagent $(0.5 \mathrm{~mL}, 50 \%)$ with a known concentration of sample was taken, $\mathrm{Na}_{2} \mathrm{CO}_{3}$ solution $(1.5 \mathrm{~mL}, 15 \%)$ was added and finally distilled water was added to make the final volume up to $10 \mathrm{~mL}$. The absorbance was recorded at $760 \mathrm{~nm}$ using an UV-visible spectrophotometer (UV-1800, Shimadzu, Japan) 
after 30 minutes of incubation in dark at room temperature. The concentration of TPC was expressed as milligrams Gallic acid equivalents per $100 \mathrm{~mL}$ (mg GAE/100 mL). Total flavonoid content of the juice and wine was determined using a spectrophotometric method at $510 \mathrm{~nm}$ following a protocol as previously described by Patil et al. (2012). Values are expressed in milligrams Quercetin equivalents per $100 \mathrm{~mL}$ (mg QE/100mL).

\subsection{Determination of DPPH radical scavenging activity}

The free radical scavenging activity was estimated according to the procedure of Brand-Williams et al. (1995) and Chakraborty et al. (2015). The sample extract $(0.1 \mathrm{~mL})$ was added to freshly prepared $3.9 \mathrm{~mL}$ of DPPH $(100 \mu \mathrm{M})$ in methanol and it was kept in dark for $45 \mathrm{~min}$ incubation. Finally, absorbance was recorded at $515 \mathrm{~nm}$ with the aid of UV-visible spectrophotometer (Shimadzu UV-1800). $0.1 \mathrm{~mL}$ of methanol along with $3.9 \mathrm{~mL}$ of DPPH was considered as control. The percentage radical scavenging activity was determined according to the following equation: DPPH radical scavenging $\operatorname{activity}(\%)=\left[1-\left(\right.\right.$ absorbance $_{\text {sample }} /$ absorbance $\left.\left._{\text {control }}\right)\right] \times 100$.

\section{(a)}

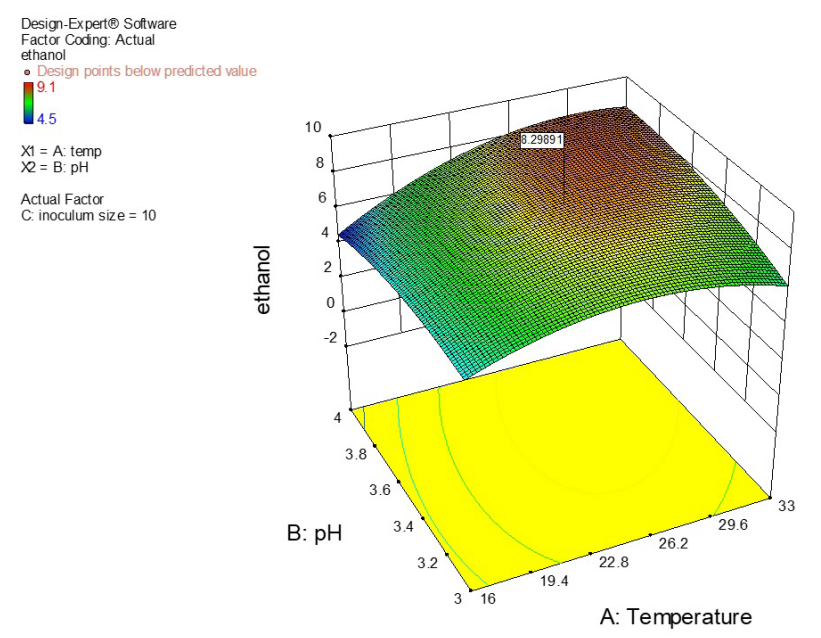

\subsection{Sensory analysis}

Sensory analysis was carried out for the optimized C. spinarum wine following the method described by Millgaard et al. (1999) and Kumar et al. (2009). Trained panelists were asked to rate for descriptors such as clarity and colour for visual appearance, odour, taste, mouthfeel and overall quality of the wine. Based on the scoring of each descriptor, the mean intensity scores were calculated.

\section{Results and discussion}

\subsection{Optimization of fermentation process parameters}

The experiment successfully indicated that all the three independent variables, i.e., temperature, $\mathrm{pH}$ and inoculum size had an profound effect on the ethanol yield, 3D response surface plots at intermediate level of temperature, $\mathrm{pH}$ and inoculum size and interaction between different variables as depicted in Figure 1a-c. Ethanol content of wine varied from 4.6-9.1\% (v/v) depending upon the variable temperature $\left(20-30^{\circ} \mathrm{C}\right), \mathrm{pH}(3-4)$ and inoculum size $(5-15 \% \mathrm{v} / \mathrm{v})$. The gradual increase in the temperature and

\section{(b)}

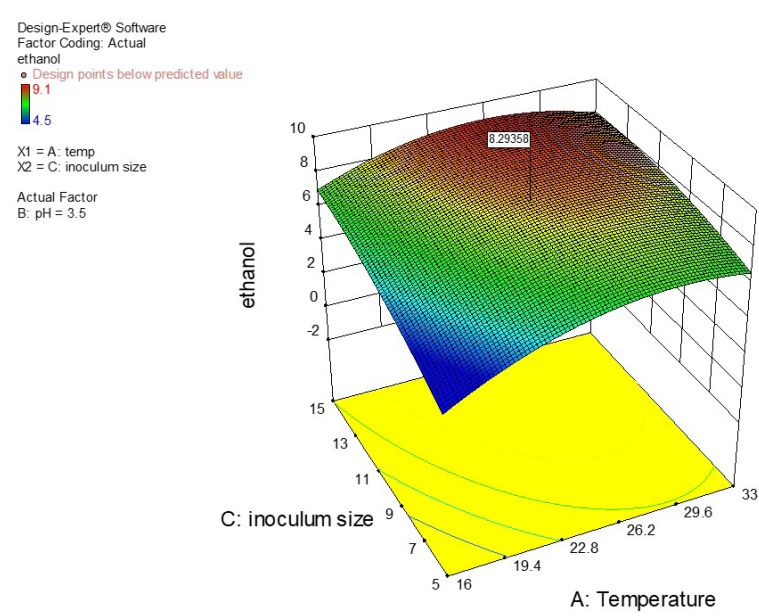

(c)

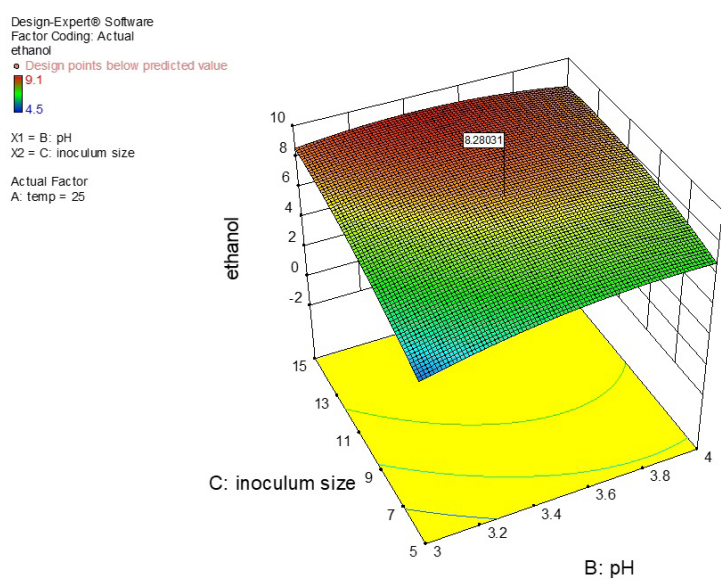

Figure 1. 3D surface plots of temperature vs. $\mathrm{pH}$ (a), temperature vs. inoculum size (b) and $\mathrm{pH}$ vs. inoculum size (c) on ethanol content. 
inoculum size resulted in higher values of ethanol. However, several previous reports confirmed that the fermentation carried at higher temperature may result in elevated levels of glycerol and higher alcohols (Jackson, 2000). Thus, resulting wine is considered to be less superior affecting taste, flavor, aroma and quality of a wine (Duarte et al., 2010; Ifie et al., 2016). Moreover, at different temperatures the growth and performance of yeast strains varies widely. In the present study, the optimized temperature of $25^{\circ} \mathrm{C}$ and inoculum size of $10 \%$ gave better results with ethanol content of $8.3 \%(\mathrm{v} / \mathrm{v})$, which could be related with the earlier report of Kumar et al. (2009), wherein their study demonstrated that optimal conditions required for mango wine production were temperature of $22.3^{\circ} \mathrm{C}$ and inoculum size of $11.9 \%$ that yielded ethanol concentration of $10 \% \mathrm{v} / \mathrm{v}$. Furthermore, another study on preparation of guava wine confirmed that at temperature of $25^{\circ} \mathrm{C}$ and inoculum size of $8 \%$ resulted in maximum ethanol content (Sevda \& Rodrigues, 2011). Nevertheless, higher inoculum size increases the production cost in winemaking. $\mathrm{pH}$ of the wine is considered as an important attribute that significantly enhances the organoleptic properties and provides suitable atmosphere for the yeast growth (Fleet \& Heard, 1993; Arroyo-López et al., 2009). In the present study, it was observed that at reduced $\mathrm{pH}$ there was notable decrease in ethanol content (Figure 1c). The optimized $\mathrm{pH}$ of 3.5 yielded higher ethanol content and was found to be in reasonable agreement in comparable to that of mango wine (3.8), guava wine (3.5) and plum wine (3.0) (Kumar et al., 2009; Sevda \& Rodrigues, 2011; Miljić \& Puškaš, 2014). Regardless of intrinsic methodological differences, many previous reports suggested that these three primary factors are influential and have a significant effect on the growth rate, metabolism rate, viability, enzymatic activity and sensitivity of yeast cells during the course of fermentation (Reddy \& Reddy, 2011; Bleoanca \& Bahrim, 2013). Thus, the present study indicated that C. spinarum fruits could be utilized for the production of good quality wine in 21 days with the following optimized conditions: temperature of $25^{\circ} \mathrm{C}$, pH of 3.5 and inoculum size of $10 \%$.

Analysis of the variance (ANOVA) pointed out that models are significant with respect to ethanol concentration (Table 3). The quadratic model thus generated could successfully explain that the three variables mainly, temperature $(\mathrm{p}<0.0001)$, $\mathrm{pH}(\mathrm{p}<0.01)$ and inoculum size $(\mathrm{p}<0.01)$ are having a profound effect on the ethanol content. In addition, the interactions between temperature and $\mathrm{pH}(\mathrm{p}<0.01)$, temperature and inoculum size $(\mathrm{p}<0.05)$ and $\mathrm{pH}$ and inoculum size $(\mathrm{p}<0.01)$ were also having a significant effect on the ethanol content. Fisher's test with a very low probability value $[(\mathrm{P}$ model $>\mathrm{F})=0.0500]$ indicate that model terms are significant. Coefficient of determination R-Square value was 0.9720 indicated model's goodness of fit. The predicted $\mathrm{R}$-Square value of 0.7650 was in reasonable agreement with the Adjusted R-Squared value of 0.9468 . F-value of 38.6 implies $0.01 \%$ chance that an F-value large could occur due to noise. Thus, the final equation of process variables in terms of coded values on developed model for the production of $C$. spinarum wine is as follows: Ethanol $=8.31+0.52 \mathrm{~A}+0.31 \mathrm{~B}+1.22 \mathrm{C}+0.48 \mathrm{AB}-0.32 \mathrm{AC}-$ $0.52 \mathrm{BC}-0.51 \mathrm{~A}^{2}-0.61 \mathrm{~B}^{2}-0.52 \mathrm{C}^{2}$.

To validate the predicted response, another batch of fermentation as a confirmatory run with the optimized conditions were conducted in triplicate. The result found was in accordance with the predicted response and the ethanol content observed was $8.3 \pm 0.3 \%$.

\subsection{Physicochemical characteristics of C. spinarum juice and wine}

The various physicochemical attributes of C. spinarum juice (day 0 ) and wine (day 21) were evaluated and results are tabulated in Table 4 . TSS of the C. spinarum juice was $22^{\circ}$ Brix on day 0 and on day 21 the TSS reached to $6.2^{\circ} \mathrm{Brix}$ with increase in alcohol content up to $8.3 \% \mathrm{v} / \mathrm{v}$, implying that in the present study the yeast was able to convert 75\% (approx.) of sugars in to ethanol. The C. spinarum wine had a $\mathrm{pH}$ of 3.4 which is favorable as reduced $\mathrm{pH}$ increases wine quality and stability. Titrable acidity increased during the course of fermentation and finally wine had $1.1 \% \mathrm{CAE}$ this can be correlated with the decreased $\mathrm{pH}$. Generally, fortified

Table 3. Analysis of variance (ANOVA) for the selected quadratic model of central composite design.

\begin{tabular}{lcccrr}
\hline \multicolumn{1}{c}{ Source } & $\begin{array}{c}\text { Sum of } \\
\text { Squares }\end{array}$ & $\begin{array}{c}\text { Degree of } \\
\text { Freedom }\end{array}$ & $\begin{array}{c}\text { Mean } \\
\text { Square }\end{array}$ & $F$ Value & $p$-value \\
\hline Model & 41.0 & 9 & 4.6 & 38.6 & $<0.0001$ \\
A-Temperature & 3.6 & 1 & 3.6 & 30.7 & 0.0002 \\
B-pH & 1.3 & 1 & 1.3 & 11.4 & 0.0071 \\
C-Inoculum size & 20.2 & 1 & 20.2 & 171.5 & $<0.0001$ \\
AB & 1.8 & 1 & 1.8 & 15.3 & 0.0029 \\
AC & 0.8 & 1 & 0.8 & 7.2 & 0.0233 \\
BC & 2.2 & 1 & 2.2 & 18.7 & 0.0015 \\
A $^{2}$ & 3.7 & 1 & 3.7 & 31.3 & 0.0002 \\
B $^{2}$ & 5.4 & 1 & 5.4 & 45.8 & $<0.0001$ \\
C $^{2}$ & 3.9 & 1 & 3.9 & 33.5 & 0.0002 \\
Residual & 1.2 & 10 & 0.1 & & \\
Lack of Fit & 1.2 & 5 & 0.2 & & \\
Pure Error & 0.00 & 5 & 0.0021 & & \\
Cor Total & 42.2 & 19 & & & \\
\hline
\end{tabular}

Table 4. Physicochemical composition and antioxidant activity of C. spinarum fruit juice and wine*.

\begin{tabular}{lcc}
\hline \multicolumn{1}{c}{ Attributes } & Juice (day 0) & $\begin{array}{c}\text { Optimized wine } \\
\text { (day 21) }\end{array}$ \\
\hline TSS ( ${ }^{\circ}$ Brix) & $22 \pm 0.00$ & $6.2 \pm 0.01$ \\
$\mathrm{pH}$ & $3.5 \pm 0.00$ & $3.4 \pm 0.01$ \\
Titrable acidity (\%) & $0.9 \pm 0.03$ & $1.1 \pm 0.08$ \\
Ascorbic acid (mg/100 g) & $20.3 \pm 0.83$ & $16.2 \pm 0.7$ \\
Total phenolics (mg GAE/100mL) & $162.1 \pm 2.2$ & $134.9 \pm 1.5$ \\
Flavonoids (mg QE/100 mL) & $52.1 \pm 1.6$ & $47.0 \pm 1.1$ \\
DPPH activity (\%) & $51.3 \pm 3.1$ & $40.1 \pm 1.8$ \\
Alcohol (\% v/v) & $\mathrm{NE}$ & $8.3 \pm 0.3$ \\
Protein (\%) & $1.2 \pm 0.2$ & $0.52 \pm 0.1$ \\
Iron (mg/L) & $1.5 \pm 0.2$ & $0.97 \pm 0.1$ \\
Calcium (mg/L) & $15.9 \pm 1.1$ & $11.5 \pm 1.8$ \\
Potassium (mg/L) & $13.3 \pm 1.4$ & $9.9 \pm 1.1$ \\
Copper (mg/L) & $0.26 \pm 0.0$ & $0.25 \pm 0.05$ \\
Zinc (mg/L) & $0.81 \pm 0.0$ & $0.22 \pm 0.04$ \\
Manganese (mg/L) & $1.76 \pm 0.0$ & $0.34 \pm 0.01$ \\
\hline
\end{tabular}

$\mathrm{NE}=$ Not evaluated $;{ }^{*}$ mean of triplicate determinations as mean \pm standard error. 
wine and table wine contains high ethanol up to $15 \%$ and $10 \%$, respectively.

Ethanol content of $8.3 \%(\mathrm{v} / \mathrm{v})$ found in the present study was higher when compared to wines obtained from other tropical fruits by various workers including cashew apple (5\%), jamun (6\%), bael (8.13\%) and lesser compared to that of mango (10\%) and pineapple wine (0.6-11\%) (Mohanty et al., 2006; Chowdhury \& Ray, 2007; Kumar et al., 2009; Chakraborty et al., 2015). The mineral content of both juice and wine was analyzed and the results have been tabulated in Table 4 . The results indicated that both juice and wine had fair amount of minerals. Ascorbic acid is a potential antioxidant found abundantly in citrus fruits and other tropical fruits. It is commonly known as vitamin $\mathrm{C}$ which effectively fights against free radicals generated by oxidative stress. The juice and wine of C. spinarum fruit had ascorbic content of 20.2 and $16.2 \mathrm{mg} / 100 \mathrm{~g}$, respectively.

\subsection{Total phenolic and flavonoid content of C. spinarum wine}

Polyphenols play a significant role in diet and their regular consumption helps to fight the free radicals. During the course of winemaking process polyphenol content of the wine widely varies. Several intrinsic and extrinsic factors affect the polyphenols concentration including steps involved in winemaking (Atanacković et al., 2012). In the present study, total polyphenols in C. spinarum juice had a phenol content of $162.2 \mathrm{mg} \mathrm{GAE} / 100 \mathrm{~mL}$, whereas the wine had $134.9 \mathrm{mg}$ GAE/ $100 \mathrm{~mL}$, a notable decrease in the polyphenol content was observed, may be due to adsorption of polyphenols onto yeast cell wall and various reactions that takes place during the fermentation process including condensation and polymerization reactions (Mena et al., 2012). According to previous studies, fruit and berry wines had a phenolic content ranging from 91-1820 mg/L (Heinonen et al., 1998), whereas, C. spinarum wine had significant amount of phenolics $(1348.8 \mathrm{mg} / \mathrm{L})$ in comparable to that of roselle wine (1363 mg/L) (Ifie et al., 2016). While, flavonoid content of juice and wine was found to be 52.1 \pm 1.6 and $47.0 \pm 1.0 \mathrm{mg} \mathrm{QE} / 100 \mathrm{~mL}$, respectively.

\subsection{Antioxidant activity}

The DPPH free radical scavenging assay is widely used to evaluate antioxidant capacity. DPPH radical scavenging activity is a well-established and most followed method that is rapid, easy and sensitive way to evaluate the antioxidant potential of a particular sample (Mundaragi \& Thangadurai, 2015). The DPPH capacity of C. spinarum juice and wine is shown in Table 4. The radical scavenging activity of C. spinarum juice and wine may be attributed to the polyphenol and ascorbic acid content present. Moreover, in the present study DPPH scavenging activity of wine was found to be slightly higher $(40.1 \pm 1.8 \%)$ when compared to the fruit wines such as custrad apple $(36.8 \pm 0.3 \%)$ and pineapple $(35.6 \pm 0.4 \%)$ (Nuengchamnong \& Ingkaninan, 2010; Jagtap \& Bapat, 2015).

\subsection{Qualitative analysis of alcohols present in C. spinarum wine}

The GC-FID analysis of alcohols revealed that ethanol was found to be most predominant with $97.8 \%$, whereas higher alcohols such as methanol, isoamyl alcohol and 1-butanol were detected in negligible concentrations with an $\%$ of $0.13,1.12$, and 0.053 , respectively. Methanol is considered to be toxic for consumption and found generally in the wine fermented from fruits comprising higher pectin content. In the present study, the smaller amount of methanol detected in the wine is a result of enzymatic hydrolysis of the pectins during winemaking (Ribéreau-Gayon et al., 1999). Nevertheless, the higher alcohols such as isoamyl alcohol and isobutanol in wine are known to emerge during fermentation due to degradation of the branched-chain amino acids or endogenous biosynthesis (Duarte et al., 2010).

\subsection{Sensory evaluation of C. spinarum wine}

Sensory analysis conducted among trained panelists of 10 members rated C. spinarum wine as 7.2 out of 10 in overall acceptability and the following sensory attributes were also considered: clarity $(7.3 \pm 0.5)$ and colour $(7.5 \pm 0.8)$ for visual appearance, odour $(7.8 \pm 0.5)$, taste $(6.9 \pm 0.6)$ and mouthfeel $(7.1 \pm 0.5)$. The wine was found to be light red in colour with fruity odour and tasted fruity to sweet. However, the wine was slight astringent in mouthfeel.

\section{Conclusion}

Based on the observations of the present study, it can be concluded that the following fermentation conditions viz., temperature of $25^{\circ} \mathrm{C}, \mathrm{pH}$ of 3.5 and inoculum size of $10 \%(\mathrm{v} / \mathrm{v})$ resulted in a maximum ethanol content. Wine prepared with above optimal conditions resulted in an ethanol yield of $8.3 \%(\mathrm{v} / \mathrm{v})$. Furthermore, physiochemical charcteristics of wine revealed that it had fair amount of essential nutrients and exhibited significant antioxidant activity. Hence, eloboration of wine from C. spinarum fruits during their glut season could reduce post harvest losses and substantially boost the consumption and utilization of fruit further adding a significant input to the local economies of rural communities.

\section{Acknowledgements}

Authors wish to acknowledge the financial support of University Grants Commission, Government of India under UGC-UPE (Non-NET)-Fellowship (KU/Sch/UGC-UPE/2014-2015/873). Special thanks to Dr. K.A. Anu-Appaiah, Principal Scientist, Department of Microbiology and Fermentation Technology, CSIR-CFTRI, Mysuru, India for invaluable technical support and encouragement received during the course of study.

\section{References}

Archana, K. M., Ravi, R., \&Anu-Appaiah, K. A. (2015). Correlation between ethanol stress and cellular fatty acid composition of alcohol producing non-Saccharomyces in comparison with Saccharomyces cerevisiae by multivariate techniques. Journal of Food Science and Technology, 52(10), 6770-6776. PMid:26396428.http://dx.doi. org/10.1007/s13197-015-1762-y.

Arroyo-López, F. N., Orlić, S., Querol, A., \&Barrio, E. (2009). Effects of temperature, $\mathrm{pH}$ and sugar concentration on the growth parameters of Saccharomyces cerevisiae, S. kudriavzevii and their interspecific hybrid. International Journal of Food Microbiology, 131(2-3), 120-127. PMid:19246112.http://dx.doi.org/10.1016/j.ijfoodmicro.2009.01.035. 
Association of Official Analytical Chemists - AOAC. (2005). Official methods of analysis of the Association of Official Analytical Chemists (18th ed.). Gaithersburg: AOAC.

Atanacković, M., Petrović, A., Jović, S., Gojković-Bukarica, L., Bursać, M., \&Cvejić, J. (2012). Influence of winemaking techniques on the resveratrol content, total phenolic content and antioxidant potential of red wines. Food Chemistry, 131(2), 513-518. http:// dx.doi.org/10.1016/j.foodchem.2011.09.015.

Bleoanca, I., \&Bahrim, G. (2013). Overview on brewing yeast stress factors. Romanian Biotechnological Letters, 18(5), 8559-8572.

Brand-Williams, W., Cuvelier, M. E., \&Berset, C. (1995). Use of a free radical method to evaluate antioxidant activity. LebensmittelWissenschaft + Technologie, 28(1), 25-30. http://dx.doi.org/10.1016/ S0023-6438(95)80008-5.

Caputi, A., Veda, M., \&Brown, T. (1968). Spectrophotometric determination of ethanol in wine. American Journal of Enology and Viticulture, 19, 160-165.

Chakraborty, K., Saha, V., Raychaudhuri, V., \&Chakraborty, R. (2015). Optimization of bioprocessing parameters using response surface methodology for bael (Aegle marmelos L.) wine with the analysis of antioxidant potential, colour and heavy metal concentration. Nutrafoods, 14(1), 39-49. http://dx.doi.org/10.1007/s13749-014-0064-8.

Chauhan, A., Tanwar, B., \&Arneja, I. (2015). Influence of processing on physiochemical, nutritional and phytochemical composition of Carissa spinarum (Karonda) fruit. Asian Journal of Pharmaceutical and Clinical Research, 8(6), 254-259.

Chowdhury, P., \&Ray, R. C. (2007). Fermentation of Jamun (Syzgium cumini L.) fruits to form red wine. ASEAN Food Journal, 14(1), 15-23.

Duarte, W. F., Dias, D. R., Oliveira, J. M., Teixeira, J. A., Silva, J. B. A., \&Schwan, R. F. (2010). Characterization of different fruit wines made from cacao, cupuassu, gabiroba, jaboticaba and umbu gabiroba. Lebensmittel-Wissenschaft + Technologie, 43(10), 1564-1572. http:// dx.doi.org/10.1016/j.lwt.2010.03.010.

Fatima, A., Singh, P. P., Agarwal, P., Irchhaiya, R., Alok, S., \&Verma, A. (2013). Treatment of various diseases by Carissa spinarum L.: a promising shrub. International Journal of Pharmaceutical Sciences and Research, 4(7), 2489-2495.

Fleet, G. H., \&Heard, G. M. (1993). Yeasts: growth during fermentation. In G. H.Fleet (Ed.), Wine microbiology and biotechnology (pp. 2755). Chur: Harwood Academic Publishers.

Heinonen, I. M., Lehtonen, P. J., \&Hopia, A. I. (1998). Antioxidant activity of berry and fruit wines and liquors. Journal of Agricultural and Food Chemistry, 46(1), 25-31. PMid:10554191.http://dx.doi. org/10.1021/jf970489o.

Ifie, I., Marshall, L. J., Ho, P., \&Williamson, G. (2016). Hibiscus sabdariffa (Roselle) extracts and wine: Phytochemical profile, physicochemical properties, and carbohydrase inhibition. Journal of Agricultural and Food Chemistry, 64(24), 4921-4931. PMid:27226105.http://dx.doi. org/10.1021/acs.jafc.6b01246.

Jackson, R. S. (2000). Wine science. Cambridge: Academic Press.

Jagtap, U. B., \&Bapat, V. A. (2015). Phenolic composition and antioxidant capacity of wine prepared from custard apple (Annona squamosa L.) fruits. Journal of Food Processing and Preservation, 39(2), 175-182. http://dx.doi.org/10.1111/jfpp.12219.

Kumar, Y. S., Prakasam, R. S., \&Reddy, O. V. S. (2009). Optimisation of fermentation conditions for mango (Mangifera indica L.) wine production by employing response surface methodology. International Journal of Food Science \& Technology, 44(11), 2320-2327. http:// dx.doi.org/10.1111/j.1365-2621.2009.02076.x.

Mena, P., Gironés-Vilaplana, A., Martí, N., \&García-Viguera, C. (2012). Pomegranate varietal wines: Phytochemical composition and quality parameters. Food Chemistry, 133(1), 108-115. http:// dx.doi.org/10.1016/j.foodchem.2011.12.079.

Miljić, U. D., \&Puškaš, V. S. (2014). Influence of fermentation conditions on production of plum (Prunus domestica L.) wine: A response surface methodology approach. Hemijska Industrija, 68(2), 199-206. http://dx.doi.org/10.2298/HEMIND130307044M.

Millgaard, M., Civille, G. V., \&Carr, B. T. (1999). Sensory evaluation techniques (3rd ed.). Boca Raton: CRC Press.

Mohanty, S., Ray, P., Swain, M. R., \&Ray, R. C. (2006). Fermentation of Cashew (Anacardium occidentale L.) "Apple" into wine. Journal of Food Processing and Preservation, 30(3), 314-322. http://dx.doi. org/10.1111/j.1745-4549.2006.00067.x.

Mundaragi, A., \&Thangadurai, D. (2015). Proximate composition, nutritive value and antioxidant activity of Flacourtia montana J. Graham. (Salicaceae). Vegetos, 28(4), 181-187. http://dx.doi. org/10.5958/2229-4473.2015.00102.0.

Nuengchamnong, N., \&Ingkaninan, K. (2010). On-line HPLC-MSDPPH assay for the analysis of phenolic antioxidant compounds in fruit wine: Antidesma thwaitesianum Muell. Food Chemistry, 118(1), 147-152. http://dx.doi.org/10.1016/j.foodchem.2009.04.069.

Patil, R. P., Pai, S. R., Pawar, N. V., Shimpale, V. B., Patil, A. M., \&Nimbalkar, M. S. (2012). Chemical characterization, mineral analysis, and antioxidant potential of two underutilized berries (Carissa carandus and Eleagnus conferta) from the Western Ghats of India. Critical Reviews in Food Science and Nutrition, 52(4), 312-320. PMid:22332595.http://dx.doi.org/10.1080/10408398.2010.500227.

Reddy, L. V. A., \&Reddy, O. V. S. (2011). Effect of fermentation conditions on yeast growth and volatile composition of wine produced from mango (Mangifera indica L.) fruit juice. Food and Bioproducts Processing, 89(4), 487-491. http://dx.doi.org/10.1016/j.fbp.2010.11.007.

Ribéreau-Gayon, P., Glories, Y., Maujean, A., \&Dubourdieu, D. (1999). Handbook of Enology: the chemistry of wine stabilization and treatments (Vol. 2). New York: John Willey and Sons.

Sevda, S. B., \&Rodrigues, L. (2011). Fermentative behavior of Saccharomyces strains during Guava (Psidium guajava L.) must fermentation and optimization of Guava wine production. Journal of Food Processing \& Technology, 2, 2-9.

Singleton, V. L., Orthofer, R., \&Lamuela-Raventos, R. M. (1974). Analysis of total phenols and other oxidation substrates and antioxidants by means of Folin-Ciocalteu reagent. Methods in Enzymology, 299, 152-178. http://dx.doi.org/10.1016/S0076-6879(99)99017-1.

Stoclet, J. C., Chataigneau, T., Ndiaye, M., Oak, M. H., El-Bedoui, L., Chataigneau, M., \&Schini-Kerth, V. B. (2004). Vascular protection by dietary polyphenols. European Journal of Pharmacology, 500(1-3), 299313. PMid:15464042.http://dx.doi.org/10.1016/j.ejphar.2004.07.034.

Styger, G., Prior, B., \& Bauer, F. F. (2011). Wine flavor and aroma. Journal of Industrial Microbiology and Biotechnology, 38(9), 11451159. http://dx.doi.org/10.1007/s10295-011-1018-4.

Thimmaiah, S. K. (1999). Standard methods of biochemical analysis. Noida: Kalyani Publishers. 